\title{
Nephropathy in cadmium workers: assessment of risk from airborne occupational exposure to cadmium
}

\author{
M J THUN,' ANA MARIA OSORIO,' SUSAN SCHOBER,' W H HANNON, ${ }^{2}$ \\ BRENDA LEWIS, ${ }^{2}$ W HALPERIN' \\ From the National Institute for Occupational Safety and Health,' Industrywide Studies Branch, Cincinnati, OH \\ 45226, and Center for Environmental Health and Injury Control, ${ }^{2}$ Division of Environmental Health Laboratory \\ Sciences, Centers for Disease Control, Atlanta, GA,USA
}

\begin{abstract}
To assess the quantitative relation between exposure to airborne cadmium and various markers of renal tubular and glomerular function, 45 male workers employed at a plant that recovers cadmium from industrial waste and 32 male hospital workers of similar age and geographical location were examined. Cumulative external exposure to airborne cadmium (dose) was estimated from historical air sampling data, adjusted for respirator use. Increasing cadmium dose was associated with multiple renal tubular functional abnormalities, including reduced reabsorption of beta-2microglobulin $(\beta-2)$, retinol binding protein (RBP), calcium, and phosphate. Serum creatinine concentration also increased with cadmium dose, suggesting impaired glomerular function. Mean systolic and diastolic blood pressures were higher in the cadmium workers than in the unexposed (134 $v 120 \mathrm{~mm} \mathrm{Hg}$ and $80 v 73 \mathrm{~mm} \mathrm{Hg}$ respectively), but only systolic blood pressure was significantly associated with cadmium dose in multivariate analyses. Cadmium dose remained the most important predictor of serum creatinine concentration after controlling for age, blood pressure, body size, and other extraneous factors. Logistic regression to model the probability (prevalence) of various renal abnormalities with increasing dose of cadmium was used. The probability of multiple tubular abnormalities and raised serum creatinine concentration increased sharply at cumulative cadmium exposures exceeding $300 \mathrm{mg} / \mathrm{m}^{3}$ days, corresponding to working for 4.3 years at the current permissible United States exposure limit for cadmium dust.
\end{abstract}

Cadmium and its compounds are used in electroplating, pigments, plastics, nickel cadmium batteries, and brazing. 'An estimated 100000 workers in the United States are exposed occupationally. ${ }^{2}$ A much larger population is exposed either by living in the vicinity of non-ferrous smelters or by consuming food or tobacco grown on contaminated soil. ${ }^{1}$

Chronic cadmium poisoning is known to cause an acquired Fanconi syndrome, a constellation of aminoaciduria, low molecular weight proteinuria, glycosuria, phosphate wasting, and altered calcium metabolism. ${ }^{3}$ The diagnosis of cadmium nephropathy is usually made presumptively by documenting increased urinary excretion of small proteins such as beta-2-microglobulin $(\beta-2)$ and retinol binding protein (RBP) in subjects with known exposure to cadmium.

Accepted 28 November 1988
Although the tubular effects of cadmium are well recognised, controversy exists about the dose of cadmium at which nephropathy appears and about the significance of $\beta-2$ and other renal tubular abnormalities in predicting progressive loss of glomerular function. The relation between cadmium and conditions related to kidney function such as hypertension, kidney stones, and altered calcium phosphorous metabolism also remains controversial.

To assess the quantitative relation between exposure to cadmium, various markers of renal tubular and glomerular dysfunction, and disorders potentially related to cadmium and nephropathy, we examined workers exposed to cadmium at a metal recovery plant in Colorado. The population is unique in that airborne exposures to cadmium were extremely high in the past, the workforce is stable, and concentrations of airborne cadmium have been measured regularly in nearly all departments since the 1940s. 


\section{Background}

Since 1925 the plant has recovered cadmium from "bag house" dust, a byproduct of non-ferrous smelting. The details of the process have been described previously. ${ }^{4-6}$ In brief, dust containing cadmium and smaller amounts of copper, selenium, thallium, arsenic, and indium was, until 1983, roasted, calcined, and processed electrolytically to recover cadmium. The cadmium was further refined in separate buildings into metal or highly purified particulate oxide and sulphide. Other metals were separated out in either the roasting or electrolytic processes but were not further refined at this plant. Litharge, or technical grade lead oxide, was processed intermittently in a separate building by one or two workers. Cadmium, as either dust or fume, was the predominant exposure at the plant, although other metals were present.

Industrial hygiene measurements of atmospheric concentrations of cadmium have been obtained by the company since 1940 . These data were previously compiled to $1979,{ }^{4-6}$ and were extended by us to 1985 (table 1). The concentration of cadmium in inhaled air is estimated as the geometric mean of all breathing zone samples multiplied by 0.25 for those departments and periods in which respirators were used. A full description of the industrial hygiene methods is published elsewhere. ${ }^{46}$

\section{Subjects and methods}

\section{SUBJECTS}

The target population included all 19 active production workers and all 27 highly exposed former workers who were alive, residing locally, and reachable by telephone. Eligible former workers were identified from a masterlist of employees previously included in a retrospective cohort mortality study. ' The unexposed population consisted of male workers employed at a local hospital. The latter were frequency matched on age to the cadmium workers.

\section{DATA COLLECTION}

The study consisted of a questionnaire; measurement of height, weight, and blood pressure; collection of a "spot" daytime urine and serum sample; and pulmonary function testing. Only the renal results will be reported here. The questionnaire collected information about characteristics such as age, history of diabetes, hypertension, prostatic disease, use of phenacetin, smoking, and occupational and recreational exposures to cadmium, lead, and solvents. Blood pressure was measured by a single examiner using a mechanical sphygmomanometer on the right arm of subjects who had been seated for at least 15 minutes. Diastolic blood pressure was considered to be the fifth
Table 1 Estimates of inhalation exposures $\left(\mathrm{mg} / \mathrm{m}^{3}\right)$ by plant department and period*

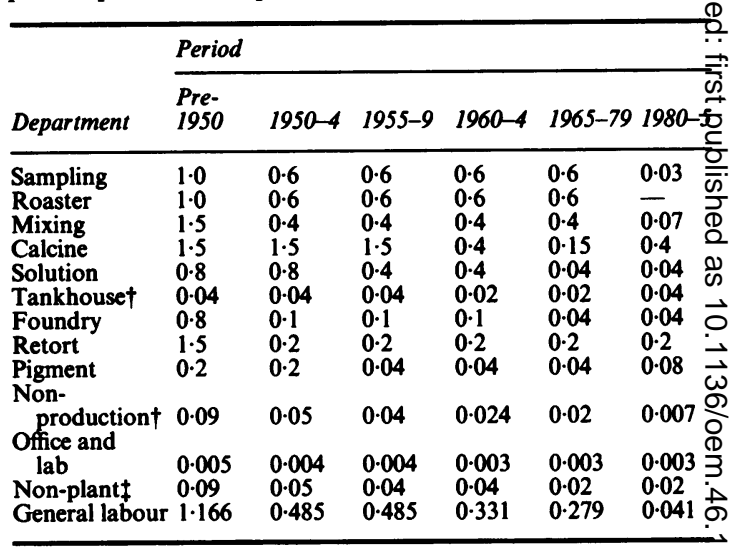

* Original estimates from Smith et $\mathrm{al}^{4}$; data on non-production and non-plant exposures added by Ellis $e t$ al. $^{5}$ Exposures from 1980 to 1985 added by us based on plant records and the assumptions of Smith et al. ${ }^{4}$

+Plant departments not directly concerned in production of cadmium (maintenance in shop, laundry, litharge, indium, thallium, janitor, zinc, supervisory in plant, selenium).

‡ob classifications with reduced exposure conditions (guard tailings dump, general labour outside plant buildings).

Korotkoff sound-disappearance of the pulse sounds $\overrightarrow{0}$

Biological markers were selected to assess sevexa!̣ types of renal dysfunction. Indices of renal tubutag function include urinary excretion of $\beta-2, \mathrm{RBP}$, cium, and phosphate. Markers of renal tubular injury (recent cellular damage) include the urinary enzymes $\mathrm{N}$-acetyl glucosaminidase (NAG), alanine amino® peptidase (AAP), and gamma-glutamyl transferase (GGT). Measurements reflecting glomerular function are serum creatinine (which increases as glomerula? filtration rate decreases) and urine albumin (whict increases with either abnormal glomerular per meability to macromolecules or with impaired tubula function). ${ }^{3}$

\section{LABORATORY METHODS}

Serum and urine $\beta-2$ were measured by radioimmune assay (Pharmacia, Piscataway, NJ, 1986), RBP by radial immunodiffusion (LC-Partigen, Behring Diag nostics, LaJolla, CA), total calcium by modified $\underset{\nabla}{ }$ cresolphthalien, creatinine by modified Jaffe methos. serum albumin by bromocresol dye binding, and serum alkaline phosphatase by $\mathrm{p}$-nitrophenylphosphate (Dupont, aca, discrete clinical analyse Wilmington, DE), inorganic phosphorous by Dupont aca autoanalyser, urinary enzymes AAP and GGT by COBAS BIO centrifugal analyser, ${ }^{8}$ NAG by modified fluorimetric assay, blood lead concentration bo atomic spectroscopy, ${ }^{10}$ blood cadmium concentration by graphite furnace atomic absorption, and urine 
cadmium concentration by a modification of the Results

method of Pruszkowska."

\section{DATA TRANSFORMATION}

To standardise for variations in serum concentration and urine volume, we expressed $\beta-2$ excretion both as $\mu \mathrm{g} / \mathrm{g}$ creatinine and as fractional excretion. ${ }^{12}$ The latter provides the best measure of the degree of tubular impairment and is computed as (urine $\beta$-2/plasma $\beta$ 2)/(urine creatinine/plasma creatinine). RBP excretion is standardised only to creatinine in urine, since the fractional excretion of RBP cannot be computed unless free, rather than total, RBP has been measured in serum. ${ }^{13}$ Albuminuria is expressed as mg albumin/ $\mathrm{mg}$ creatinine as proposed by Ginsberg $e t$ al and Shaw et al. ${ }^{14} 15$ Tubular reabsorption of phosphate (\%TRP) and of calcium (\%TRC) are used to express the tubular handling of these substances and are computed as the product of (1-fractional excretion) $\times 100$. Body mass is expressed as the Quetelet index (weight $(\mathrm{kg}) /$ height $\left.(\mathrm{m})^{2}\right)$. Body surface area $\left(\mathrm{m}^{2}\right)$ is computed as (weight $(\mathrm{kg})^{0.5378} \times$ height $\left.(\mathrm{cm})^{0.3964} \times 0.024265\right) .{ }^{16}$

\section{ESTIMATION OF EXPOSURE}

We estimated cumulative external exposure to airborne cadmium using the detailed work histories for each subject and the matrix of exposure estimates, adjusted for respirator use, for the various departments and calendar times (table 1). ${ }^{46}$ We multiplied the number of days a worker spent in a given department/time by the estimated exposure level (mg/ $\mathrm{m}^{3}$ ) in that department/time. The sum represents the worker's cumulative external exposure or dose. We also measured cadmium in blood and urine and blood lead concentration. Blood and urine samples were collected away from the workplace in an office setting. Current workers had showered since last exposure to cadmium.

\section{STATISTICAL ANALYSES}

Variables with a skewed distribution were logarithmically transformed to approximate the normal distribution. Student's $t$ test was used to test the difference between group means for continuous variables and $\chi^{2}$ to test association between dichotomous variables. Potential confounders were included in regression analyses if associated with both exposure and outcome at $p<0 \cdot 1$. Stepwise multiple linear regression was used to identify those independent variables and two way interaction terms that best explained each of the renal outcomes of interest. Logistic regression was used to determine the probability of renal outcomes being "abnormal" at various exposure levels, when abnormal was defined by the geometric mean in the unexposed minus two SDs (for \% TRC and \% TRP) or plus two SDs (for $\beta-2$, RBP, and creatinine).
Forty five cadmium workers and 32 unexposed hospital workers took part in the study. Participation among current cadmium production workers was $17 / 19(89 \%)$ and among highly exposed former workers $18 / 27(67 \%)$. Two salaried workers and eight former short term production workers not in the target population also took part. Reasons offered for nonparticipation were illness (4), desire not to offend the company (2), exposure too long ago (1), and unspecified (4). Non-exposed hospital workers were initially recruited from the maintenance department (12) and shipping and food service (7). Older unexposed subjects were subsequently recruited from office workers (6) and professionals (7).

We observed several demographic differences between the cadmium exposed and comparison populations (table 2). The cadmium workers were slightly older (mean age $54 v 50, \mathrm{p}=0.2$ ) and more likely to be Hispanic $(58 \% v 16 \%, \mathrm{p}<0.0001)$. The exposed workers were shorter and heavier than the unexposed, resulting in a significantly higher mean Quetelet index $(29.5 v 26.3, \mathrm{p}=0.001)$. Fewer of the cadmium workers were current smokers $(38 \% v 44 \%$, $\mathrm{p}=0.6$ ) and of those who had ever smoked, they had consumed fewer pack-years on average (14.6 v 22.1, $\mathrm{p}=0 \cdot 29$ ).

Measures of exposure to cadmium and lead are also included in table 2. Blood cadmium concentrations were significantly higher in the exposed workers than in the unexposed $(7.9 v 1.2 \mu \mathrm{g} / \mathrm{l}, \mathrm{p}<0.0001)$, as was urine cadmium $(9.3 v 0.7 \mu \mathrm{g} / \mathrm{g}$ creatinine, $\mathrm{p}<0.0001)$. The average blood lead concentration was higher in the cadmium workers than in the unexposed (11.9 v $8.3 \mu \mathrm{g} / 1, \mathrm{p}=0.0013)$. The highest current blood lead concentration was $32.6 \mu \mathrm{g} / \mathrm{l}$.

Table 2 Selected characteristics of 77 study participants

\begin{tabular}{|c|c|c|}
\hline & $\begin{array}{l}\text { Cadmium workers } \\
(n=45)\end{array}$ & $\begin{array}{l}\text { Unexposed } \\
(n=32)\end{array}$ \\
\hline \multirow{4}{*}{$\begin{array}{l}\text { Personal characteristics: } \\
\text { Age (mean } \pm \text { SD) } \\
\text { Per cent Hispanic } \\
\text { Quetelet index } \\
\text { (mean } \pm \text { SD) } \\
\text { Per cent current } \\
\text { smokers } \\
\text { Pack-years smoked } \\
\text { (mean } \pm \text { SD) }\end{array}$} & $\begin{array}{l}54 \cdot 4 \pm 15 \cdot 5 \\
58 \%\end{array}$ & $\begin{array}{l}50 \cdot 1 \pm 13 \cdot 0 \\
16 \%\end{array}$ \\
\hline & $29 \cdot 5 \quad(4 \cdot 9)$ & $26 \cdot 3$ \\
\hline & $38 \%$ & $44 \%$ \\
\hline & $14.6 \quad(19.8)$ & $22 \cdot 1 \quad(29 \cdot 4)$ \\
\hline \multirow{5}{*}{$\begin{array}{l}\text { Exposure characteristics: } \\
\text { Years of cadmium work } \\
\text { (GM, range) } \\
\text { Cumulative exposure } \\
\text { (mg/m }{ }^{3} \text { days) } \\
\text { Blood cadmium }(\mu \mathrm{g} / \mathrm{l}) \\
\text { (GM } \pm \text { SD) } \\
\text { Urine cadmium }(\mu \mathrm{g} / \mathrm{g} \\
\text { creatinine) }(\mathrm{mean} \pm \mathrm{SD}) \\
\text { Blood lead }(\mu \mathrm{g} / \mathrm{l}) \\
(\mathrm{GM} \pm \mathrm{SD})\end{array}$} & $19(1-38)$ & 0 \\
\hline & $604 \quad(0-5383)$ & 0 \\
\hline & $7.9 \pm 2.0$ & $1 \cdot 2 \pm 2.0$ \\
\hline & $9.3 \pm 6.9$ & $0.7 \pm 0.7$ \\
\hline & $11.9 \pm 1.8$ & $8.3 \pm 1.4$ \\
\hline
\end{tabular}


Several medical conditions were reported more commonly by the cadmium workers than by the unexposed. These included kidney stones $(18 \% v 3 \%$, $\mathrm{p}=0.07)$, prostatic disease $(20 \% \vee 6 \%, \mathrm{p}=0.09)$, diabetes $(18 \% \vee 3 \%, \mathrm{p}=0.07)$, and hypertension $(38 \% v 16 \%, \mathrm{p}=0.03)$. All these differences between the exposure groups were evaluated as potential confounders or intermediate variables in subsequent multivariate analyses.

Selected clinical measurements are presented in table 3. The cadmium workers had significantly higher systolic $(133.9 v 120.3 \mathrm{~mm} \mathrm{Hg}, \mathrm{p}=0.0004)$ and diastolic $(80.0 \vee 73.3 \mathrm{~mm} \mathrm{Hg}, \mathrm{p}=0.0019)$ blood pressure than the unexposed. Eight cadmium workers and three controls had diastolic blood pressures above $90 \mathrm{~mm} \mathrm{Hg}$ (Fisher's exact test $\mathrm{p}=0.35$ ). Eleven cadmium workers and two controls had systolic blood pressures above $150 \mathrm{~mm} \mathrm{Hg}\left(\chi^{2}=4 \cdot 4, \mathrm{p}=0.036\right)$.

Indices of renal function are shown graphically in fig 1 , and summarised numerically in table 3 . Tubular dysfunction appears in a subgroup of cadmium workers as increased urinary excretion of $\beta-2$ and RBP and decreased tubular reabsorption of calcium and phosphate. No evidence of enzymuria, reflecting recent necrosis of tubular epithelium, is seen in the cadmium workers. Glomerular dysfunction is manifest as a small increase in mean serum creatinine concentration. Urinary albumin excretion is higher in the cadmium workers than in the unexposed, but the increase is mild and could reflect either a pure tubular

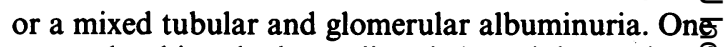
exposed subject had an albumin/creatinine ratio of over $0.2 \mathrm{mg} / \mathrm{mg}$; the value for this subject $(0.2 \mathrm{~F}$ $\mathrm{mg} / \mathrm{mg}$ ) was substantially below the ratio of $\geq 3$. . observed in nephrotic syndrome. ${ }^{14}$

Table 3 also shows that the excretion of $\beta-2$ is highef in the cadmium workers when expressed as eithef concentration ( $\mu \mathrm{g} / \mathrm{g}$ creatinine) or as fractional excre tion. Thus the increased excretion of this proteif reflects renal tubular dysfunction, not simple increased serum concentrations.

Excretion of $\beta-2$ is highly correlated with othe indices of kidney dysfunction. Correlation coefficients between $\beta-2(\mu \mathrm{g} / \mathrm{g}$ creatinine) and other markers are as follows: $R B P(R=0.91, p<0.0001), \% T R E$ $(R=-0.63, p<0.0001), \% T R C(R=-0.530$ $\mathrm{p}<0.0001)$, and serum creatinine $\left(\mathrm{R}=0.51^{3}\right.$ $\mathrm{p}<0.0001$ ).

Clinically significant abnormalities are clustered i $\vec{B}$ the ten cadmium workers whose urinary $\beta-2$ excretio. exceeds $1000 \mu \mathrm{g} / \mathrm{g}$ creatinine. For example, three of these have serum creatinine $\geq 1.8 \mathrm{mg} / \mathrm{dl}$, four have serum phosphorous below $2.5 \mathrm{mg} / \mathrm{dl}$, and four have$\%$ TRP $<65 \%$, whereas none of the 32 unexpose workers had similar abnormalities. Mildly raise serum alkaline phosphatase $(>170$ Internationa Units) was measured in three of the 10 cadmium $^{-}$ workers with the highest $\beta-2$ versus one of the 38 unexposed. A detailed clinical presentation of she metabolic abnormalities will be presented elsewher.

Table 3 Measurements related to renal function in the cadmium exposed and comparison workers

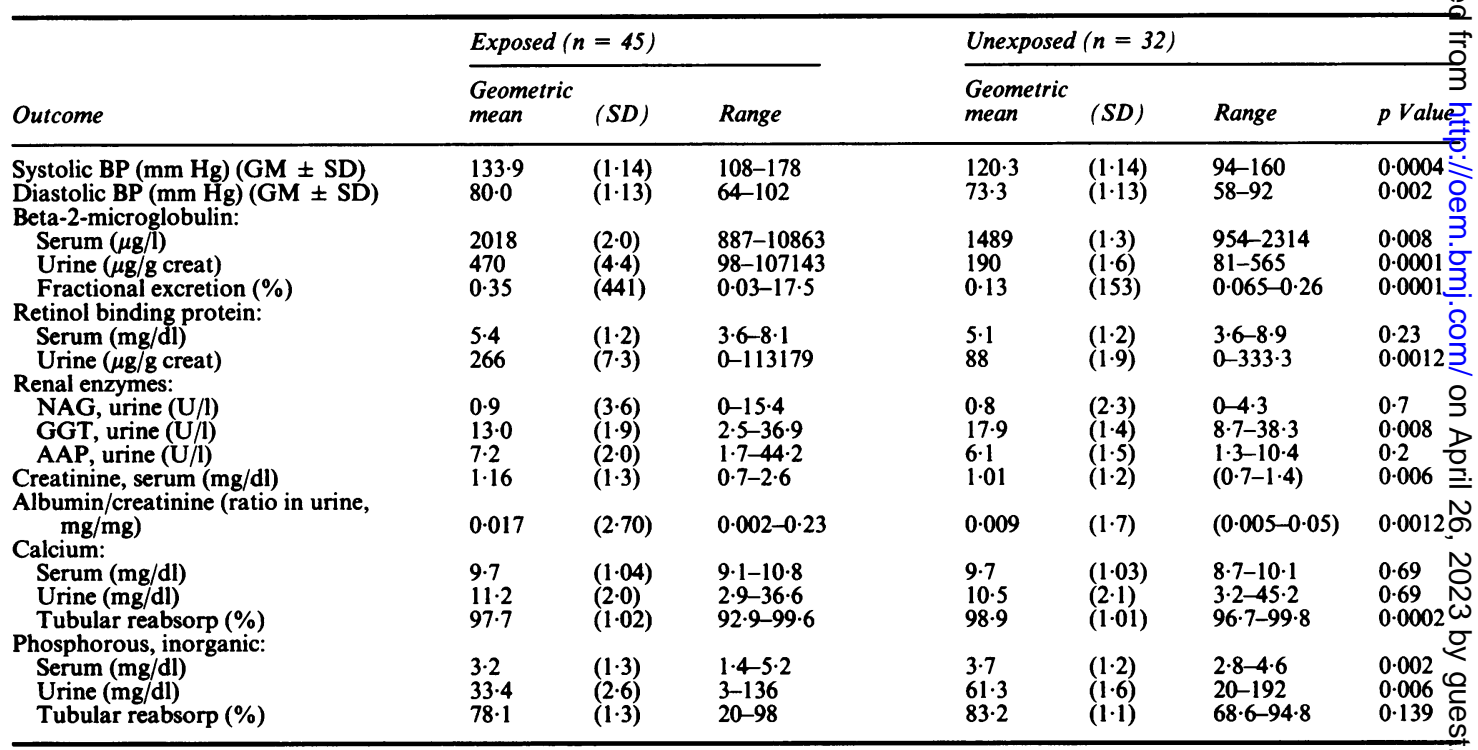

NAG $=\mathrm{N}$-acetyl glucosaminidase. GGT = Gamma-glutamyl transferase. AAP = Alanine aminopeptidase. 
MULTIPLE REGRESSION ANALYSES

Multiple regression is used to determine which variables best explain the renal tubular and glomerular outcomes. Cumulative exposure (dose) is chosen as the exposure variable because, in our data, it correlates more closely with the renal outcomes than does urine
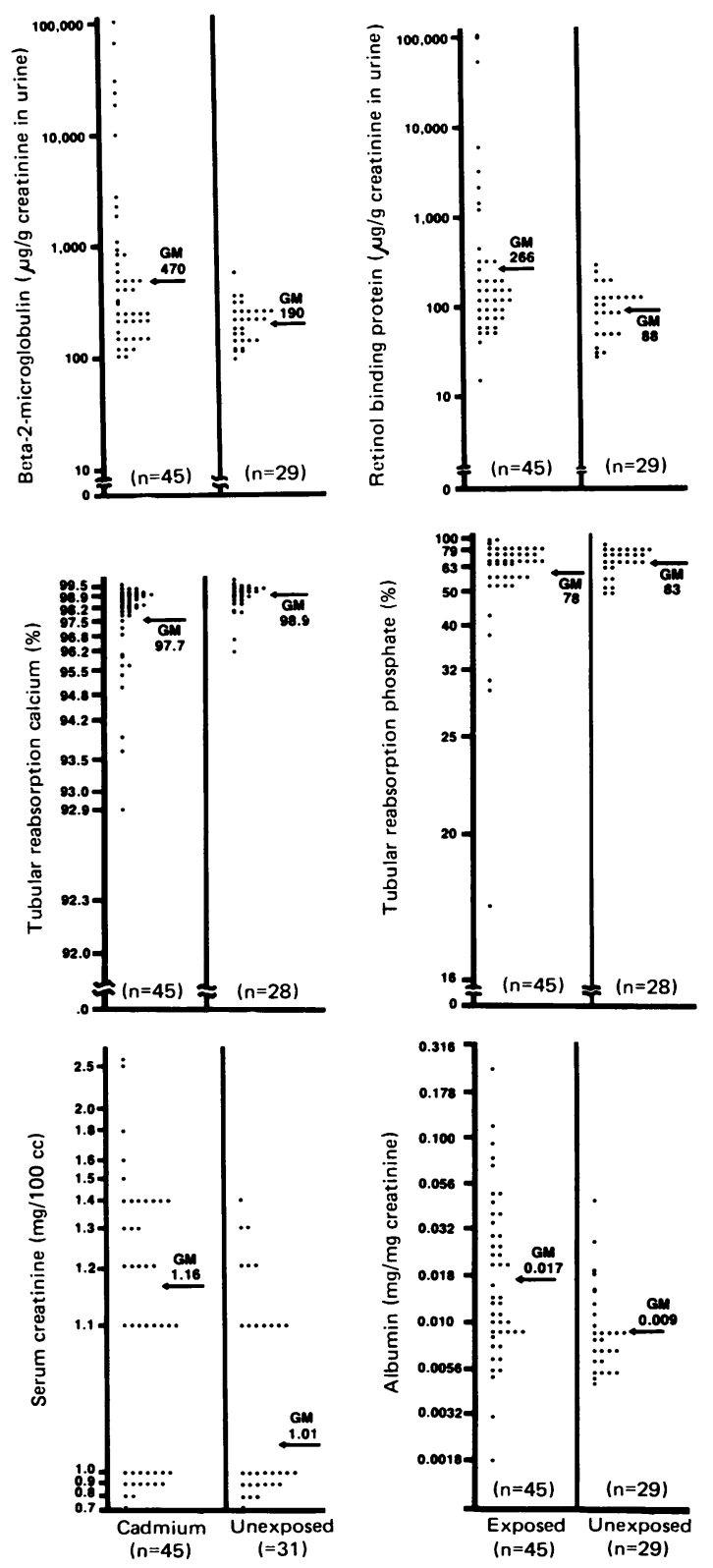

Fig 1 Indices of renal function in workers exposed and unexposed to cadmium. cadmium concentration. We also included age, systolic and diastolic blood pressure, Hispanic ethnicity, months since last exposure to cadmium, Quetelet index, body surface area, history of hypertension, prostatic disease, and diabetes, and blood lead concentration.

Figure 2 shows the data points, regression line, and $95 \%$ upper and lower confidence intervals for the models best explaining $\beta-2$, RBP, \%TRC, \%TRP, and serum creatinine concentration. Table 4 presents the actual regression models. The diagrams in fig 2 consider only variables that are significant at the p $<0.05$ level. Those models that include age (RBP and \% TRC) are illustrated with age arbitrarily fixed at the mean age of the population ( 52.6 years).

Dose is the single most important variable associated with all of the renal outcomes. Consistent with a renal tubular toxin that impairs reabsorption of $\beta-2, \mathrm{RBP}$, calcium, and phosphate, cadmium dose is positively associated with tubular proteinuria $(\beta-2$, RBP) and negatively associated with \%TRC and \%TRP. Dose is also positively associated with serum creatinine consistent with a glomerular effect. Cadmium dose explained $50 \%$ of the variance of $\beta-2$, $45 \%$ of RBP, $27 \%$ of \%TRC, $23 \%$ of serum creatinine, and $18 \%$ of $\%$ TRP.

When $\beta-2$ is re-expressed as fractional excretion, dose is again the single most important predictor (table 4 , subscript). The association between dose and $\beta-2$ diminished slightly when $\beta-2$ was expressed as fractional excretion.

Time since last exposure to cadmium was not an important determinant of any renal outcome, either by itself or as a modifier of cadmium dose. Most of the workers with high $\beta-2$ excretion had not been exposed for several years. For example, nine of the $15(60 \%)$ cadmium workers with the highest $\beta-2$ excretion had not been exposed to cadmium for at least five years, and one for 45 years.

We looked particularly closely at whether the higher serum creatinine concentrations in the cadmium workers might be explained by a known risk factor such as age, diabetes, prostatic disease, or hypertension rather than cadmium. The relation between cadmium dose and serum creatinine concentration persisted even when we excluded from the analysis all those with current diastolic blood pressure $\geq 90 \mathrm{~mm} \mathrm{Hg}$, systolic pressure $\geq 150 \mathrm{~mm} \mathrm{Hg}$, or positive history of diabetes, prostatic disease, or hypertension, while controlling for age, ethnicity, and blood lead concentration (coefficient for dose $x$ $10^{-4}=0.476, p=0.0007$ ). We also tested whether kidney stones might provide a mechanism linking cadmium to increasing serum creatinine concentrations by excluding subjects with kidney stones from the regression analysis. The coefficient for dose 

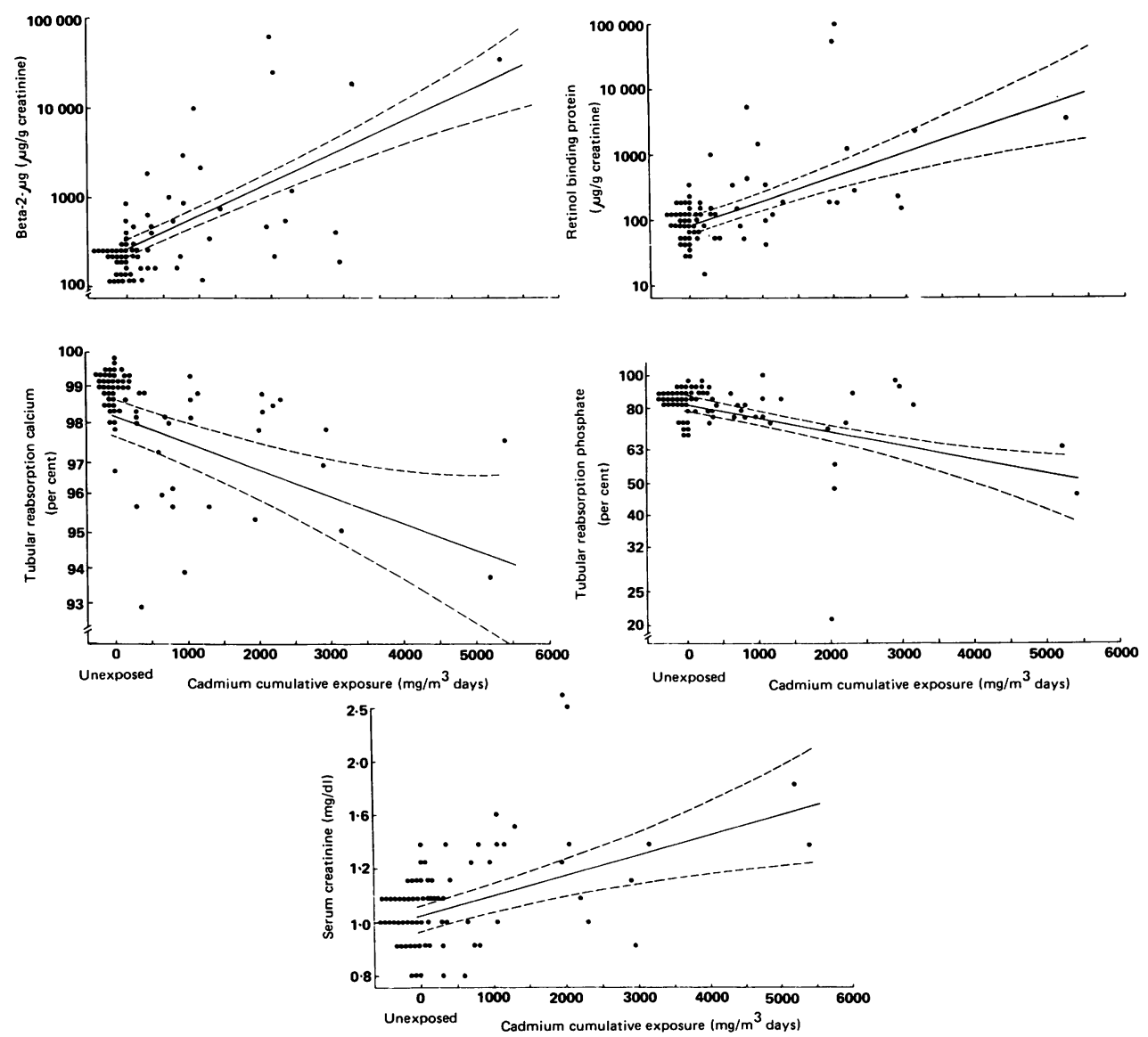

Fig 2 Regression of various renal endpoints versus cadmium dose. (Regression line models described in table 4.)

remained essentially unchanged $(0.34 v 0.41$ dose $\times$ $10^{-4}$, suggesting that the association between cadmium and serum creatinine concentration is not dependent on kidney stones.

To test whether extreme or outlying data points might distort the slope of any of these regression lines, we repeated the analyses in table 3 after excluding the most extreme outliers. Outliers were excluded if the residual (observed value-predicted value) exceeded the 95th percentile. Exclusion of outliers had a negligible effect on the coefficient for dose for any of the renal endpoints. In all cases the $F$ value for dose remains highly significant. In the absence of a cogent reason to exclude the outliers we present the full data.

Table 4 and fig 2 do not show the relation between cadmium dose, systolic or diastolic blood pressure, or albuminuria. Dose is a statistically significant predictor of systolic but not of diastolic blood pressure, after controlling for age, Quetelet index ethnicity, and blood lead concentration. As dose increases from 0 to $5000 \mathrm{mg} / \mathrm{m}^{3}$ days, mean predicted systolic blood pressure increases from 125.9 to $145.3 \mathrm{~mm} \mathrm{Hg}\left(\log \mathrm{SBP}=2.10+0.1246 \times\right.$ dose $x_{0}$ $\left.10^{-4}, \mathrm{p}=0.04\right)$. Dose is also a statistically significan? predictor of the urinary albumin/creatinine ratio, as are age and systolic blood pressure. We do not presen this model because of space limitations and becausE the relation of albuminuria to dose does not clarify whether the urinary albumin reflects a pure tubular of a mixed tubular and glomerular lesion.

PREVALENCE OF RENAL ABNORMALITIES VERSUS EXPOSURE

Figure 3 illustrates the probability of having various 
Table 4 Regression models best explaining renal outcomes

\begin{tabular}{|c|c|c|c|c|c|}
\hline & $B$ & $S E$ & $F$ & $p$ & $R^{2}$ \\
\hline $\begin{array}{l}\text { Beta-2-microglobulir } \\
\text { Intercept } \\
\text { Dose }\left(\times 10^{-4}\right) \dagger\end{array}$ & $\begin{array}{l}\text { in }(\log \mu \mathrm{g} / \mathrm{E} \\
2.323 \\
4 \cdot 195\end{array}$ & creatinine & $71 \cdot 1$ & $<0.0001$ & 0.50 \\
\hline $\begin{array}{l}\text { Retinol binding prot } \\
\text { Intercept } \\
\text { Dose }\left(\times 10^{-4}\right) \dagger \\
\text { Age }(y)\end{array}$ & $\begin{array}{c}\text { tein }(\log \mu \\
1.457 \\
3.657 \\
0.010\end{array}$ & $\begin{array}{l}0.6633 \\
0.005\end{array}$ & $\begin{array}{r}55 \cdot 6 \\
4 \cdot 2\end{array}$ & $\begin{array}{c}<0.0001 \\
0.044\end{array}$ & $\begin{array}{l}0.45 \\
0.03\end{array}$ \\
\hline $\begin{array}{l}\text { Tubular reabsorptio } \\
\text { Intercept } \\
\text { Dose }\left(\times 10^{-4}\right) \dagger \\
\text { Age }(y) \\
\text { Diabetes } \$\end{array}$ & $\begin{array}{c}\text { n calcium } \\
1.999 \\
-0.029 \\
-0.0001 \\
0.0044\end{array}$ & $\begin{array}{l}(\log \%): \\
0.007 \\
0.00005 \\
0.0025\end{array}$ & $\begin{array}{r}16 \cdot 3 \\
4 \cdot 0 \\
3 \cdot 2\end{array}$ & $\begin{array}{l}0.0001 \\
0.05 \\
0.08\end{array}$ & $\begin{array}{l}0.27 \\
0.03 \\
0.03\end{array}$ \\
\hline $\begin{array}{l}\text { Tubular reabsorptio } \\
\text { Intercept } \\
\text { Dose }\left(\times 10^{-4}\right) \dagger \\
\text { Prostatic disease }\end{array}$ & $\begin{array}{l}\text { n phosph } \\
1.931 \\
-0.325 \\
-0.051\end{array}$ & $\begin{array}{l}0.088 \\
0.027\end{array}$ & $\begin{array}{r}15.5 \\
3.5\end{array}$ & $\begin{array}{l}0.0002 \\
0.065\end{array}$ & $\begin{array}{l}0.18 \\
0.04\end{array}$ \\
\hline $\begin{array}{l}\text { Serum creatinine (lo } \\
\text { Intercept } \\
\text { Dose }\left(\times 10^{-4}\right) \dagger \\
\text { Prostatic disease } \ddagger\end{array}$ & $\begin{array}{c}\mathrm{g} \mathrm{mg} / \mathrm{dl}): \\
0.008 \\
0.414 \\
0.050\end{array}$ & $\begin{array}{l}0.094 \\
0.029\end{array}$ & $\begin{array}{r}21.9 \\
2.9\end{array}$ & $\begin{array}{l}0.0001 \\
0.09\end{array}$ & $\begin{array}{l}0.23 \\
0.03\end{array}$ \\
\hline
\end{tabular}

*Log FE (fractional excretion) $\beta-2=-2.82+3.08$ dose $\times 10^{-4}$ $R^{2}=0.38, F=44.4$

†Units of dose are $\mathrm{mg} /$ cubic $\mathrm{m}^{3}$ days.

$\ddagger$ Diabetes or prostatic disease (by history) are indicator variables.

renal abnormalities versus cumulative exposure to cadmium. The definitions of "abnormal" are specified in the legend for figure 3 and are defined based on the unexposed workers. The prevalence of abnormalities increases with cumulative exposure to cadmium; multiple renal abnormalities become apparent in subjects with cumulative exposure $\geq 300 \mathrm{mg} / \mathrm{m}^{3}$ days. The logistic regression lines shown in fig 3 actually overestimate the prevalence of renal dysfunction among cadmium workers with low cumulative exposure. Only one of $17(5.9 \%)$ cadmium workers below this dose had any renal abnormality, whereas 23 of $28(82 \cdot 1 \%)$ workers above it had some renal dysfunction and 17 of these had multiple abnormalities. These data suggest a threshold for renal dysfunction occurring at about $300 \mathrm{mg} / \mathrm{m}^{3}$ days.

A similar analysis was performed using urine cadmium concentration as the measure of exposure. To compare our data to those of Nogawa et $a^{17}$ we adopted their definition of abnormal for urinary $\beta-2$ (>5 mg $\beta-2 / 1$ ). The probability of an abnormal $\beta-2$ was somewhat higher for a given concentration of urine cadmium in our study than in that of Nogawa $e t$ $a l$. For example, a urine cadmium concentration of $3 \cdot 2$ $\mu \mathrm{g} / \mathrm{g}$ creatinine was associated with a $1 \%$ prevalence of abnormal $\beta-2$ in the study of Nogawara et al versus $2 \cdot 8 \%$ in ours. ${ }^{17}$

\section{Discussion}

The cross sectional data presented here help to quantify the relation between exposure to cadmium and several parameters of renal tubular and glomerular dysfunction. Increased cumulative exposure to cadmium (dose) is accompanied by increased low and high molecular weight proteinuria, reduced calcium and phosphorous reabsorption, and rising serum creatinine concentration. While these data are cross sectional rather than longitudinal, they provide an important link in the theoretical continuum bet-

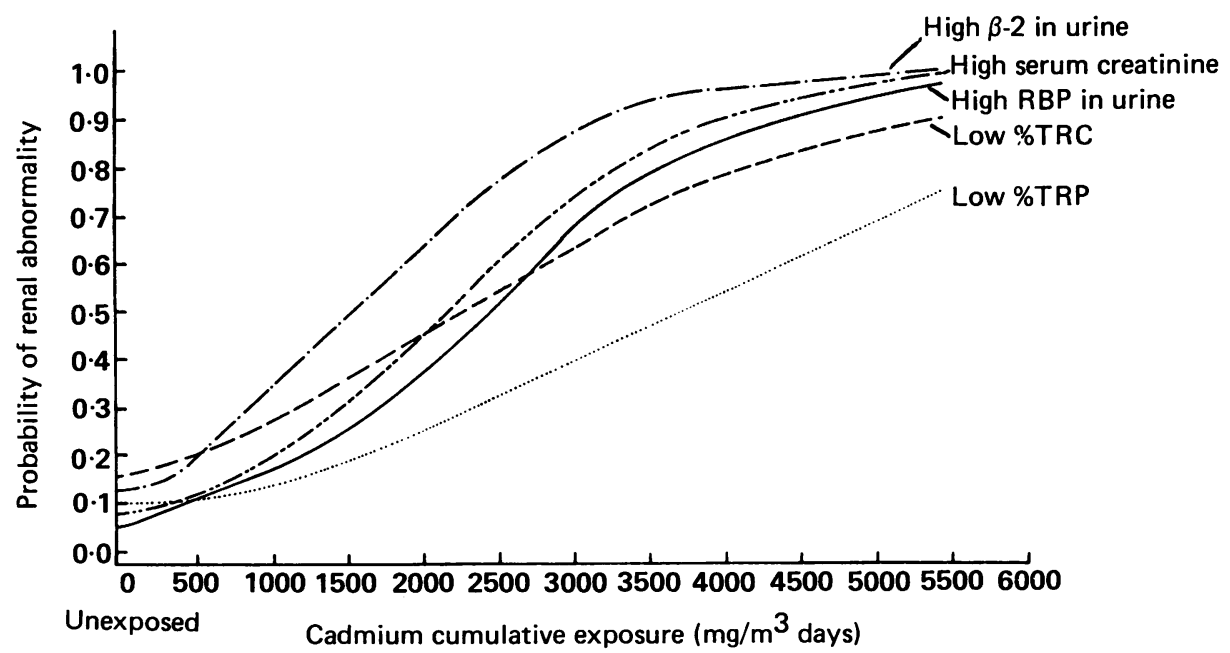

Fig 3 Probability of renal abnormality versus cadmium cumulative exposure. Abnormal renal tests defined as follows: high $\beta-2>486 \mu \mathrm{g} / \mathrm{g}$ creatinine, high serum creatinine $\geqslant 1.4 \mathrm{mg} / \mathrm{dl}$, high $R B P>321 \mu \mathrm{g} / \mathrm{g}$ creatinine, low $T R P<69.4 \%$, low $T R C<97.56 \%$. 
ween the subacute renal toxicity and more serious long term sequelae of cadmium exposure.

The extensive numbers of reports on cadmium nephropathy suggest that at least two manifestations of renal dysfunction may be of particular clinical and public health importance. Firstly, disturbed calcium phosphorous metabolism, manifest in our study by phosphaturia, low serum phosphorous, and low tubular reabsorption of calcium are postulated to contribute to the bone disease and kidney stone formation observed in certain groups exposed to cadmium. $^{318}$ Secondly, progressive loss of renal tubular function may cause, or be accompanied by, a more subtle reduction in GFR and increased serum creatinine. $^{3}$

An epidemic of severe bone disease occurred in Japan among women consuming rice contaminated with cadmium. ${ }^{18} 19$ The syndrome was called Itai itai (ouch ouch) disease, and was manifest by bone pain, skeletal deformities, and spontaneous fractures. Even in villages where rice was heavily contaminated with cadmium, clinical osteopathy was confined to poorly nourished, postmenopausal women, suggesting that cadmium precipitated clinical disease in those at high risk due to nutritional and endocrinologic factors. ${ }^{1819}$

Similar bone disease has been rare in occupational populations. Bone pain and spontaneous fractures were reported in British and French alkaline battery workers near the end of the second world war. ${ }^{1820}$ In general, however, male workers with adequate nutrition do not experience spontaneous fractures or radiological abnormalities and female workers have not been studied longitudinally for the occurrence of osteopathy after menopause.

A second potential consequence of hypercalcuria or phosphaturia is susceptibility to kidney stones. Kidney stones are common in cadmium exposed populations, with lifetime prevalence reportedly ranging from $19 \%$ to $44 \% .{ }^{3}$ In our study eight $(18 \%)$ of the 45 cadmium workers had experienced kidney stones versus one $(3 \%)$ of the 32 unexposed. Several mechanisms could link stone formation to renal tubular disease, including hypercalcuria, phosphaturia, uricaciduria, reduced urinary citrate, or renal tubular acidosis. $^{21}$ The field techniques used in our study did demonstrate differences in calcium and phosphorous excretion associated with the cadmium workers but were not designed to be a complete clinical or metabolic evaluation. Future research should attempt to characterise the urinary composition of cadmium workers in a more controlled clinical setting.

Field investigators have generally been unable to study the effects of cadmium on glomerular filtration rate (GFR). Friberg, in Scandinavia, measured insulin clearance in 19 heavily exposed alkaline battery workers. GFR was below population normals in these workers but the study could not control for age ō relate inulin clearance to quantified exposure levels. $\frac{2 \rho}{3}$ Adams found increased serum creatinine concentra $\overrightarrow{\mathrm{D}}$ tion in nearly all of 23 workers with severe tubular? proteinuria.$^{23}$ Our study is unique in relating increas $\overrightarrow{\vec{*}}$ ing serum creatinine concentration to quantified dose of cadmium. It is also the first to use multivariate techniques to determine that cadmium, rather than $\overline{\text { : }}$. age, hypertension, or other extraneous variables bese explains this relation. Although serum creatinine concentration is less sensitive than creatinine or inulinin clearance as a measure of GFR, using serum creatinines concentration as the marker of glomerular functionis more likely to obscure a true association withw cadmium than to create a false positive one. The theoretical possibility exists that cadmium mighe increase serum creatinine concentration by a tubular $r_{A}$ mechanism, selectively decreasing postglomerular secretion of creatinine by the nephron while sparing $\vec{D}$ tubular reabsorption. Such an explanation is unsup-o ported by experimental studies of cadmium.

Evidence of tubular dysfunction persists in some workers in our study for decades after the cessation of exposure to cadmium. Other investigators have notech that $\beta-2$ persists and even increases in some workerso after employment ceases. ${ }^{3}$ The issue of the reversibilityo of nephropathy is controversial, however, partlybecause longitudinal data are rarely available ando\% partly because the assay for $\beta-2$ has increased on sensitivity over time. In our study multiple tubufarg lesions were manifest in workers who had retired manys years before. Furthermore, in multiple regressiono analyses time away from cadmium did not appear to modify the association between cadmium dose and any renal endpoint. These data suggest that if cadmium nephropathy is reversible the recovery is sog slow as to be undiscernable in our data set.

The significantly higher systolic and diastolic blooof pressure in the cadmium workers, relative to the unexposed, is an interesting and a potentially $\frac{\mathrm{P}}{3}$ important finding. It resurrects a longstanding debate about whether cadmium can cause hypertension in man. Hypertension has been observed experimentallyo in rats drinking cadmium contaminated water ${ }^{24}$ It has? been sought for but rarely found in studies of highly exposed workers. ${ }^{25} \mathrm{~A}$ theory has been advanced that low doses of cadmium may increase, and higher doses may decrease, blood pressure in man. ${ }^{25}$ Blood pressure measurements in our study were performed by a single examiner using one instrument. We did not expect an association between blood pressure and cadmium Rather we measured blood pressure as a factor to be $e^{\omega}$ controlled in the analysis of serum creatinine concen $\%$ tration. Neither hypertension by history nor currene blood pressure explained the relation between exposure to cadmium and serum creatinine concentra- 
tion. Whether or not hypertension is itself caused by exposure to cadmium is an issue for future study. Our analysis provides reasonable certainty that hypertension is not an extraneous factor causing an artifactual association between cadmium and serum creatinine concentration in our data.

Estimating the "critical dose" of cadmium necessary to induce nephropathy depends on both the choice of renal endpoints and on the definition of abnormal. Our definitions of abnormal (fig 3) are based on the fifth or 95th percentile of test results in the unexposed population. The probability of abnormality, by this definition, increases sharply as cumulative exposure to cadmium rises above $300 \mathrm{mg}$ / $\mathrm{m}^{3}$ days. Subjects whose cumulative exposure exceeds this level often manifest multiple renal tubular abnormalities, with raised $\beta-2, \mathrm{RBP}$, and low \%TRC appearing at similar exposure levels.

A final question concerns whether current occupational standards protect against cadmium nephropathy. The safe level of cadmium clearly depends on the criteria for renal injury and the expected working lifetime. If $300 \mathrm{mg} / \mathrm{m}^{3}$ days is judged to be safe, based on the above reasoning, then this exposure is exceeded by working for 4.3 years at the current United States permissible exposure limit of $200 \mu \mathrm{g} / \mathrm{m}^{3}$ for cadmium dust averaged over an eight hour workday. ${ }^{26}$ Average exposure would need to be reduced by a factor of over ten to protect workers over a 45 year working lifetime. These results support a recommendation by a working group of the World Health Organisation to limit exposures to $10 \mu \mathrm{g} / \mathrm{m}^{327}$ and a similar recommendation by the United States National Institute for Occupational Safety and Health to limit occupational exposure to cadmium to the fullest extent feasible. ${ }^{2}$

We thank Dr Dennis Waite, Dr Kathleen Kreiss, and staff of the National Jewish Center for Immunology and Respiratory Medicine for providing a comparison population, the United Steelworkers of America for the examining facility, Ms Brenda Lewis for laboratory help, Dr Richard Hornung for statistical advice, and Drs Gary Diamond, Robert Goyer, Theodore Meinhardt, Steven Teutsch, and Richard Wedeen for their thoughtful review of the manuscript.

\section{References}

1 Elinder CG. Cadmium: uses, occurrence, and intake. In: Friberg L, Elinder C, Kjellstrom T, Nordberg G, eds. Cadmium and health: a toxicological and epidemiological appraisal. Vol 1. Boca Raton: CRC Press, 1986:23-63.

2 National Institute for Occupational Safety and Health, Center for Disease Control, Public Health Service. Current intelligence bulletin 42, Cadmium (CD), Cincinnati: NIOSH, 1984. (DHHS (NIOSH) publ no 84-116.)

3 Kjellstrom T. Renal effects. In: Friberg L, Elinder C, Kjellstrom T, Nordberg G, eds. Cadmium and health: a toxicological and epidemiological appraisal. Vol 2. Boca Raton: CRC Press, 1986: 21-109.

4 Smith TJ, Anderson RJ, Reading JC. Chronic cadmium exposures associated with kidney function effects. Am J Ind Med 1980; 1:319-37.

5 Ellis KJ, Cohn SH, Smith TJ. Cadmium inhalation exposure estimates: their significance with respect to kidney and liver cadmium burden. J Toxicol Environ Health 1985;15:173-87.

6 Smith TJ, Ferrell WC, Varner MO, Putnam RD. Inhalation exposure of cadmium workers: effects of respirator usage. Am Ind Hyg Assoc J 1980;41:624-9.

7 Thun MJ, Schnorr TM, Smith AB, Halperin WE, Lemen RA Mortality among a cohort of cadmium production workers-an update. JNCI 1985;74:325-33.

8 Mueller PW, MacNeil ML, Steinberg KK. Stabilization of alanine aminopeptidase, gamma glutamyltranspeptidase, and $\mathrm{N}$-acetyl$\beta$-D-glucosaminidase activity in normal urines. Arch Environ Contam Toxicol 1986;15:343-7.

9 Leaback DH, Walker PG. Studies on glucosaminidase. 4. The fluorimetric assay of $\mathrm{N}$-acetyl- $\beta$-glucosaminidase. Biochem $J$ 1961;78:151-6.

10 Paschal DC, Bell CJ. Improved accuracy in the determination of blood lead by electrothermal atomic absorption. Atomic Spectroscopy 1981;2:146-50.

11 Pruszkowska E, Carnrick GR, Slavin W. Direct determination of cadmium in urine with use of a stabilized temperature platform furnace and zeeman background correction. Clin Chem 1983; 29:477-80.

12 Thun MJ, Clarkson TW. Spectrum of tests available to evaluate occupationally induced renal disease. J Occup Med 1986;28: 1026-33.

13 Bernard A, Vyskocl A, Mahieu P, Lauwerys R. Effect of renal insufficiency on the concentration of free retinol-binding protein in urine and serum. Clin Chim Acta 1988;171:85-94.

14 Ginsberg JM, Chang BS, Matarese RA, et al. Use of single voided sample to estimate quantitative proteinuria. $N$ Engl J Med 1983 309:1543-6.

15 Shaw AB, Risdon P, Lewis-Jackson JD. Protein creatinine index and Albustix in assessment of proteinuria. $\mathrm{Br}$ Med $\mathrm{J} 1983$ 287:929-32.

16 Haycock GB, Schwartz GJ, Wisotsky DH. Geometric method for measuring body surface area: $a$ height-weight formula validated in infants, children, and adults. $J$ Pediatr 1978;93:62-6.

17 Nogawa K, Kobayashi E, Honda R. A study of the relationship between cadmium concentrations in urine and renal effects of cadmium. Environ Health Perspect 1979;28:161-8.

18 Kjellstrom $T$. Effects on bone, on vitamin $D$, on calcium, metabolism. In: Friberg L, Elinder C, Kjellstrom T, Nordberg $\mathrm{G}$, eds. Cadmium and health: a toxicological and epidemiological appraisal. Vol 2. Boca Raton: CRC Press, 1986:111-58.

19 Tsuchiya K, ed. Cadmium studies in Japan: a review. Amsterdam: Elsevier/North-Holland Biomedical Press, 1978.

20 Adams RG, Harrison JF, Scott P. The development of cadmium induced proteinuria, impaired renal function, and osteomalacia in alkaline battery workers. $Q J$ Med 1969;38:425-43.

21 Coe FL, Favus MJ. Idiopathic hypercalcuria in calcium nephrolithiasis. Disease of the Month 1980;26:1-36.

22 Friberg L. Health hazards in the manufacture of alkaline accumulators with special reference to chronic cadmium poisoning. Acta Med Scand 1950;138(suppl 240):1-124. (Doctoral thesis.)

23 Adams RG. Clinical and biochemical observations in men with cadmium nephropathy. A twenty year study. Arh Hig Rada Toksikol 1979;30:219-31.

24 Schroeder HA, Vinton WH. Hypertension induced in rats by small doses of cadmium. Am J Physiol 1962;202:515-8.

25 Elinder CG. Other toxic effects. In: Friberg L, Elinder C, Kjellstrom T, Nordberg G, eds. Cadmium and health: a toxicological and epidemiological appraisal. Vol 2. Boca Raton: CRC Press, 1986:160-79.

26 US Department of Labor, Occupational Safety and Health Administration. Code of federal regulations. Washington: US Government Printing Office, 1981. (29 CFR 1910.1000, table Z-2.)

27 World Health Organisation. Recommended health-based limits in occupational exposure to heavy metals. Geneva: WHO, 1980. (Report of a study group, tech rep ser 647.) 